\title{
WUJUD INTEGRASI SOSIAL DALAM SISTEM BAGI HASIL TANAMAN JERUK SIAM DESA TEGALSARI KECAMATAN TEGALSARI KABUPATEN BANYUWANGI
}

\author{
Mochamad Rafi Chuluqy ${ }^{1}$ \\ ${ }^{1}$ Program Studi Sosiologi, Universitas Jember
}

\begin{abstract}
Abstrak
Penelitian ini memiliki tujuan untuk menggambarkan mekanisme sistem bagi hasil yang ada pada sektor pertanian khususnya pada tanaman jeruk siam (Citrus nobilis), dan juga manfaat mekanisme ini bagi masyarakat. Kerjasama dengan menggunakan sistem bagi hasil sudah dilakukan masyarakat daerah pedesaan sejak dulu. Dalam sistem bagi hasil, ada berbagai mekanisme kerjasama antara pemilik lahan, dan penggarap, mekanisme kerjasama itu antara lain Maro, Mertelu, dan Merpat. Penelitian dalam artikel ini merupakan penelitian kualitatif yang dilakukan di Desa Tegalsari Kecamatan Tegalsari Kabupaten Banyuwangi. Teknik observasi serta wawancara digunkan untuk memperoleh data di penelitian ini. Dalam penelitian ini diperoleh hasil yang menyatakan bahwa sistem bagi hasil juga dapat menumbuhkan solidaritas dan integrasi sosial, selain menunjukan peningkatan perekonomian yang menjadi tujuan utama sistem ini. Hal itu dibuktikan dengan adanya rasa peduli, saling percaya, saling membantu antara pemilik lahan dan penggarap jika mengalami kesulitan. Meskipun demikian, peran serta pihak lain seperti pemerintah juga tetap diperlukan agar hubungan baik antara kedua belah pihak dapat tetap terjaga.
\end{abstract}

Kata kunci: Pertanian, Sistem Bagi Hasil, Solidaritas, Integrasi Sosial.

\begin{abstract}
This study aims to describe the production sharing system in agriculture, especially in the Citrus nobilis plant, and its benefits in community life. The profit-sharing system is a form of cooperation that has existed and been carried out by the village community for a long time. In the profit-sharing system, there are various cooperation mechanisms between landowners and tenants. The cooperation mechanisms include Maro, Mertelu, and Merpat. The research in this article is a qualitative research conducted in Tegalsari Village, Tegalsari District, Banyuwangi Regency. Data collection was carried out by interview and observation techniques. The results of this study indicate that the implementation of the cooperation agreement with the profit-sharing system not only improves the economy, but also fosters solidarity and social integration in society. This is evidenced by a sense of care, mutual trust, and mutual assistance between landowners and tenants when experiencing difficulties. Even so, the participation of other parties such as the government is still needed so that good relations between the two parties can be maintained.
\end{abstract}

Keywords: Agriculture, Profit Sharing, Solidarity, Social Integration. 


\section{Pendahuluan}

Indonesia sebagai suatu negara agraris mempunyai wilayah pertanian yang luas, hal ini mejadikan sebagian besar masyarkatnya sebagai petani. Tidak dapat dipungkiri, pertanian sebagai sektor vital masayrakat desa, perkembangan dan laju pertumbuhan ekonomi yang ada di desa tidak lepas dari peranan sektor pertanian. Persoalan ketimpangan dalam kepemilikan lahan pertanian yang ada di desa bukan merupakan suatu hal yang baru. Hal ini dapat terjadi karena pertumbuhan penduduk masyarkat tidak di imbangi dengan pertambahan lahan pertanian. Pedesaan memiliki lahan pertanian yang sangat luas, akan tetapi tidak semua masyarkatnya memiliki sebidang lahan milik sendiri untuk dikelola, bagi mereka yang tidak memiliki lahan sendiri akan memilih bekerja sebagai buruh ke seseorang yang memiliki tanah yang luas.

Fedindand Husken (dalam Wahyuningsih, 2011) yang telah melakukan penelitian di Jawa Tengah, mengutarakan struktur yang terjadi atas persoalan kepemilikan tanah adalah "kerbau besar akan selalu menang jika diadu" (Kebo Gedhe Menang Berikhe). Maksut dari pernyataan tersebut adalah, meskipun jumlah seseorang yang memiliki tanah sedikit akan tetapi bisa memiliki kuasa untuk mengatur proses produksi hingga penguasaan lahan. Secara praktis, seseorang dapat menguasai daerah yang subur dan mengatur tenaga kerja, sedangkan hal berbeda terjadi pada petani penggarap, karena tidak mempunyai kuasa (powerless) maka petani penggarap hanya bisa mengolah tanag, merawat tanamn, serta mengatur pengairan hingga masa panen tiba.

Dalam Undang-undang No.2 Tahun 1960, secara garis besar mengatur tentang kerjasama yang dilakukan oleh pemilik tanah dan penggarap (seseorang ataupun badan hukum). Dalam kerjasama itu diatur juga perjanjian bagi hasil yang mengijinkan penggarap untuk mengolah tanah dan menyelenggarakan usaha pertanian di lahan miliki pemilik tanah, dan nantinya hasil usaha pertanian itu dibagi sesuai kesepakatan kedua pihak. (UU No. 2 Tahun 1960 Pasal 1 C).

Sistem bagi hasil bukan merupakan suatu hal baru dalam masyarakat khususnya masyarakat desa yang bekerja di sektor pertanian. Sistem bagi hasil ini merupakan bentuk dari kerjasama tradisional yang ada secara turun-temurun, kesepakatan kerjasama yang telah dibuat antara kedua belah pihak tercipta atas dasar saling membutuhkan, sukarela, dan bukan suatu paksaan. Dalam sistem ini, pemilik tanah dan penggarap akan sama-sama di untungkan, pemilik tanah tidak perlu bersusah payah mengelola tanah miliknya, sedangkan penggarap tidak perlu memiliki lahan sendiri untuk diolah, karena dapat mengelola lahan orang lain dan tetap mendapatkan hasil sesuai kesepakatan.

Sistem bagi hasil mempunyai mekanisme pengelolaan yang berbeda-beda tergantung mekanisme apa yang telah disepakti oleh dua pihak yang terlibat. Dalam sistem bagi hasil tanaman jeruk siam di desa Tegalsari memiliki tiga mekanisme yang pertama adalah Maro, dengan pembagian yang sama antara pemilik lahan dan penggarap yaitu 50:50, yang kedua Mertelu, dengan pembagian untuk pemilik lahan sebesar 2/3 dan bagian untuk petani penggarap sebesar $1 / 3$, yang terakhir Merpat, dalam perjanjian ini juga menenutkan jangka waktu kerjasama yang disepakati bersama-sama.

Tidak semua pemilik tanah akan bersifat adil kepada penggarap, hal ini terjadi karena kondisi dan kedudukan penggarap lemah dan sebagian dari penggarap juga tidak memiliki keahlian lain, selain bertani sehingga sulit untuk mencari pekerjaan lain. Ketidakadilan itu bisa terjadi dalam bentuk penarikan atau pembatalan kerjasama sebelum waktu yang disepakati antara keduanya. Hal ini biasanya terjadi karena sang penggarap tidak cukup memiliki kemampuan untuk mengelola lahan denngan baik sehingga pemilik tanah mengambil kembali lahan miliknya karena memiki "power" lebih daripada penggarap. 
Perjanjian bagi hasil dalam masyarakat desa di dasari oleh keadaan saling membutuhkan, dan sebagian dari mereka juga mendasarkan pada rasa saling percaya, karena para pemilik lahan memilih penggarap yang memang ia tau dan kenal, bahkan memilih kerabatnya sendiri untuk mengelola lahan pertanian miliknya. Tentu hal ini membuat pemilik lahan dan penggarap saling di untungkan, meskipun pemilik tanah mempunyai lahan yang luas bukan berarti akan dikelola sendiri, pasti juga memerlukan petani penggarap, hal yang sama juga dirasakan petani penggarap, mereka akan sangat diuntungkan oleh lahan yang dimiliki pemilik lahan karena dengan itu mereka akan tetap memperoleh penghasilan walaupun tidak punya lahan sendiri.

\section{Metode Penelitian}

Penelitian ini tergolong penelitian dengan metode kualitatif studi kasus, hal ini dikarenakan data yang telah dikumpulkan dalam penelitian tentang wujud integrasi sosial dalam sistem bagi hasil tanaman jeruk siam di desa Tegalsari ini berupa kata-kata dan juga penjelasan, bukan merupakan angka-angka. Penelitian kualitatif di definisikan oleh Bogdan dan Taylor (Moleong, 2010) sebagai prosedur penelitian yang nantinya menghasilkan data deskriptif baik berupa perkataan lisan maupun tulisan yang berasal dari perilaku seseorang yang telah diamati.

Lokasi penelitian ini berada di Desa Tegalsari Kecamatan Tegalsari Kabupaten Banyuwangi, pemilihan lokasi ini didsarkan pada kegiatan masyarakat di desa ini yang banyak menggunakan sistem bagi hasil dalam pengelolaan jeruk siam yang menjadi komoditas utama desa ini. Dalam penelitian ini, teknik purposive sampling digunakan dalam upaya penetuan sampel yang akan di pakai. Penelitian ini memfokuskan pada dua masalah, yaitu: yang pertama, untuk mengetahui sistem bagi hasil pertanian jeruk siam yang dilakukan oleh masyarakat, mekanisme bagi hasil, dan juga faktor yang dapat mempengaruhi sistem bagi hasil. Yang kedua, untuk mengetahui hubungan sistem bagi hasil dengan integrasi sosial yang akan dianalisa menggunakan teori modal sosial. Peneliti klasifikasikan informan dalam penelitian ini yaitu pemilik tanah dan penggarap tanah, serta ada juga informan pendukung seperti penebas atau pembeli jeruk.

\section{Hasil dan Pembahasan}

Pertanian merupakan sektor utama di pedesaan, masyarakatnyapun sebagian besar memiliki mata pencaharian sebagai petani, hal yang membuat sektor pertanian menjadi sektor yang identik dengan masyarakat desa. Indikator kemajuan dan perkembangan ekonomi dapat dilihat dan diukur dalam sektor pertannian ini. Pertanian desa dapat menghasilkan komoditas utama dan khas bagi tiap-tiap wilayah tergantung lahan dan faktor pendukung lainnya, seperti pertanian yang ada di Desa Tegalsari Kecamatan Tegalsari Kabupaten Banyuwangi yang memiliki komoditi unggulan berupa buah jeruk siam (Citrus nobilis) yang menjadi tanaman favorit masyarakat desa karena harga jual buah yang lebih tinggi daripada tanaman padi.

Usaha masyarakat untuk menaikkan taraf hidupnya dengan cara menanam jeruk siam sering kali menemui hambatan, terutama bagi mereka yang tidak mempunya lahan pribadi untuk di kelola. Sebenarnya, persoalan lahan bukanlah suatu permasalahan baru, persoalan lahan yang berakar pada ketimpangan dalam kepemilikan lahan dapat terjadi karena pertumbuhan penduduk yang tidak di imbangi dengan pertambahan lahan. Hal ini membuat para petani yang masih belum memiliki lahan sendiri, memilih unuk bekerja menjadi buruh kepada seseorang yang memiliki lahan. Persoalan ini buakn berarti tidak berlaku pada mereka yang memiliki lahan luas, mereka yang memiliki lahan luas juga memiliki persoalan karena tidak mampu menegelola lahannya sendiri dan membutuhkan bantuan dari petani penggarap.

\section{Kepemilikan Tanah dan Sistem Bagi Hasil}

Pulau Jawa jika dilihat dari luas wilayahnya menempati urutan kedua pulau terbesar yang ada di Indonesia setelah Pulau Kalimantan, Pulau Jawa memiliki daerah yang sebagian besar 
merupakan daerah pedasaan dan masyarakatnya sebagian besar bermata pencaharian sebagai petani sawah daripada sebagai petani tegalan. Horoyoshi Kano (dalam Wahyuningsih, 2011) menuturkan bahwa yang terpenting bagi para petani di Jawa adalah sawah dan bukan tegalan, ia juga mengklasifikasikan kepemilkan tanah, antara lain yaitu: erfelijk individueel bezit yang memiliki arti kepemilikan tanah oleh seseorang yang didapat secara turun-temurun. Kepemilikan ini merupakan suatu penguasaan sebidang tanah yang secara kekal diduduki oleh seseorang, tanah itu dapat di serahkan kepada ahli warisnya jika pemiliknya meninggal, maupun dapat juga memberikannya secara sukarela atas kemauannya sendiri. Adapun ciri paling khas dalam kepemilikan tanah model ini adalah adanya kebebasan untuk menjual, menyewakan, menggadaikan dan lainnya semau pemilik lahan.

Collier (1984) menggambarkan sifat dan kebiasaan petani Jawa, menurutnnya jika petani Jawa memiliki sebidang tanah yang berukukuran luas akan berkencenderungan untuk menyerahkan beberapa petak dari sebidang tanah itu untuk diberikan kepada petani (penggarap) lain yang tidak memiliki lahan untuk diolah sendiri, maka akan timbullah sebuah kerjasama antara pemilik tanah dan penggarap berdasarkan beberapa cara, salah satunya dengan menyewakan tanah tersebut kepada penggarap, cara ini biasanya berlangsung selama lebih dari masa satu kali panen, dengan demikian harga sewa tanah dengan jangka waktu itu, akan lebih mengungtungkan daripada tanah yang hanya di sewa dalam jangka waktu sekali panen. Namun harga sewa tidak terpaku hanya dengan janga waktu, melainkan dapat juga dipengaruhi oleh kualitas dan keadaan tanah, seberapa butuh pemilik tanah terhadap uang yang akan didapat, dan hubungan antara pemilik tanah dengan penyewa, seperti yang umum terjadi di masyarakat Jawa.

Sistem bagi hasil sendiri merupakan salah satu perjanjian kerjasama tradisional yang sudah ada secara turun temurun. Perjanjian ini melibatkan dua belah pihak yaitu pemilik tanah dan petani penggarap dengan tujuan untuk mengatasi dan meringankan permasalahan yang dimiliki oleh masing-masing pihak. Dalam kasus yang terdapat di sistem bagi hasil tanaman jeruk siam di Desa Tegalsari Kecamatan Tegalsari Kabpuatane Banyuwangi, para petani dan penggarap membagi mekanisme bagi hasil menjadi tiga bagian yaitu, Maro, Mertelu, dan Merpat. Namun yang paling banyak digunakan oleh masyarkat desa ini adalah mekanisme Maro dan Mertelu. Mekanisme Maro mendasarkan pada pembagian hasil panen sebesar 50:50 bagi pemilik maupun penggarap lahan, dan mekanisme Mertelu memiliki perbedaan dalam pembagiannya, pemilik lahan mempunyai hak sebesar $2 / 3$ dari bagian panen, sedangkan penggarap mempunyai hak sebesar $1 / 3$ bagian dari hasil panen. Dalam jangka waktu kerjasamanya juga memiliki ketentuan tertentu tergantung kesepakatan diawal, begitu pun dengan pembiayaan kedua mekanisme tersebut juga berbeda dan bertujuan untuk meringankan dan menguntungkan kedua belah pihak, sistem kerjasama tradisional ini muncul atas dasar rasa saling percaya diantara kedua pihak yang bekerja sama, karena rasa saling percaya itu, maka kerjasama ini tidak menggunakan perjanian resmi tertulis (hitam diatas putih)., dan jika ada permasalahan diantara keduanya, akan diselesaikan dengan cara musywarah tanpa melibatkan pihak berwajib.

Menurut (Pudjiawati, 2002), di berbagai daerah pedesaan yang ada di Jawa Tengah (meliputi: Banyumas, Pekalongan, Tegal, Semarang, dan Jepara) serta berbagai daerah pedesaan di Jawa Timur (meliputi: Probolinggo, Pasuruan, dan Besuki) memiliki tiga mekanisme sistem bagi hasil yang telah biasa dilakukan oleh masyarkat, yaitu: Maro, dalam mekanisme ini penggarap harus memilik kewajiban untuk membiayai bibit, pupuk, upah buruh tani (penggarap itu sendiri), maupun keperuan lain, dan juga nantinya pada saat panen tiba penggarap harus memberikan separuh dari hasil panen itu kepada pemilik tanah. Mertelu, mekanisme yang syarat-syaratnya sama dengan Maro, namun ada perbedaan pada pembagaian hasil panennya, dalam mekanisme Mertelu penggarap mendapatkan sepertiga (1/3) bagian, dan pemilik tanah mendapatkan duapertiga (2/3) bagian. Dalam mekanisme terkahir yaitu Merpat penggarap 
hanya membayar upah buruh tani(penggarap hanya bekerja pada lahan milik pemilik tanah) dan pemilik tanah yang membiayai bibit, pupuk dan keperluan lain, dengan catatan penggarap mendapatkan seperempat (1/4) bagian dari hasil panen.

Kroef (1984) dalam (Wahyuningsih, 2011) memaparkan mekanisme bagi hasil yang ada di daerah pedesaan Jawa Barat, diantaranya adalah; yang pertama mertelu mekanisme ini megharuskan pemilik tanah untuk menanggung biaya benih (dan, sampai pada saat penghapusan sistem ini, juga membayar pajak-pajak tanah) dan akan menerima dua pertiga $(2 / 3)$ bagian dari hasil panen, sisanya berhak untuk penyakap/penyewa. Kedua, merapat; persyaratannya sama dengan mertelu kecuali pemilik tanah medapatkan tiga perempat bagian dari hasil panen dan sisanya merupakan bagian dari penyewa atau penyakap. Ketiga, nyeblok atau ngepak dalam hal ini penggarap yang akan melakukan semua pekerjaan seperti bajak tanah, nyiang, hingga menanam. Dan kemudian pemilik tanah mengambil alih pekerjaan (mengarur pengairan dan panen). Nantinya penggarap akan menerima satu perlima (1/5) bagian hasil panen. Keempat yaitu derep; penggarap ataupun buruh memiliki pekerjaan utama untuk menanam padi, akan tetapi juga bisa melaukan pekerjaan lain sesuai yang diminta pemilik tanah hingga waktu panen datang. Nantinya buruh akan mendapatkan satu perlima (1/5) padi bulir, tetapi jika hasil yang didapat jelek maka bagiannya akan berkurang. Kelima, adalah gotong royong; kegiatan ini biasanya hanya melibatkan satu keluarga. Pembagian dalam sistem ini sesuai dengan apa yang telah mereka sepakati dan tentukan sebelumnya, dan juga sesuai kebiasaan dalam pembagian mekanisme bagi hasi tersebut.

\section{Modal Sosial dalam Sistem Bagi Hasil.}

Modal sosial mengacu pada berbagai aspek organisasi sosial, antara lain; kepercayaaan, normanorma, dan jejaring sosial yang dapat memfasilitasi tindakan kolektif. Pada dasarnya, modal sosial adalah bentuk dari upaya seluruh anggota masyarakat dalam rangka menaikkan taraf dan kualitas hidup secara terus menerus. Modal sosial di definisikan Burt dalam (Kusumastuti, 2016) sebagai kapasitas masyarakat untuk melakukan asosiasi (terkait) satu dengan yang lain hingga muncul kekuatan yang sangat penting, tidak hanya dalam aspek ekonomi, namun juga dalam aspek eksistensi sosial lainnya.

Tipologi modal sosial dapat berupa Bonding dan juga bridging. Modal sosial bonding biasanya ditemui pada masyrakat homogen, bentuk bonding modal sosial meliputi ide, relasi, serta perhatian yang berorientasi kedalam (inward looking). Putnam dalam (Kusumastuti, 2016) mencirikan bonding social capital dalam sacred society. Masyarkat dalam sacred society terdominasi serta bertahan pada struktur masyarakat yang totalitarian, hierarkis, serta tertutup pada suatu dogma. Dalam model interaksi seperti ini, masyarkat selalu dituntun oleh sebuah nilai dan norma yang pada akhirnya hanya menguntungkan wilayah atau hierarki tertentu.

Adapun modal sosial bridging yang memiliki sifat inklusif serta berorientasi keluar (outward looking). Berbeda dengan bonding social capital, bridging social capital lebih terbuka dan cenderung melaukan kontak serta interaksi dengan kelompok lain dalam rangka mengembangkan pembangunan. Tipologi masyarkat yang memiliki kecenderungan untuk berinteraski dan menciptakan jaringan sosial dalam gerakannya, menurut (Coleman, 1990) akan lebih mampu memberikan tekanan dalam upaya bersama kepada kelompok diluar mereka.

Secara garis besar, didalam modal sosial terdapat empat unsur utama, unsur-unsur itu meliputi; kepercayaan, hubungan timbal baik, norma, dan juga jaringan sosial. Berikut penjelaasan mengenai empat unsur tersebut;

1. Unsur pertama yang merupakan salah satu instrumen sentral dalam masyarakat yaitu Trust atau Kepercayaan, unsur ini mampu mendorong masyarakat untuk menghasilkan suatu aktifitas yang produktif dengan cara bekerja sama. Kepercayaan merupakan sebuah produk dari norma kooperatif yang mampu menstimulus adanya modal sosial. (Fukuyama, 2002) 
menjelaskan kepercayaan atau trust sebagai suatu harapan dari terciptanya keteraturan, kejujuran, dan juga perilaku kooperatif yang ada dalam komunitas dan bersandar pada norma yang telah dianut dalam komunitas tersebut.

2. Kedua, adalah hubungan timbal balik atau reciprocity yang merupakan suatu tindakan kolektif dengan tujuan saling merespon. Hubungan timbal balik dapat ditemui dalam bentuk saling memberi dan juga saling menerima, yang ada di dalam sebuah interaksi sosial. (Sanjaya dkk., 2015)

3. Ketiga, adalah Norma dan Nilai Sosial. Norma sendiri merupakan sebuah identitas yang mampu membentuk modal sosial. Norma juga dijadikan sebagai pedoman perilaku pada setiap individu, sebuah norma juga dapat menjaga eksistensi masyarkat. Setelah itu ada Nilai, Nilai adalah sesuatu yang dihargai, dibanggakan, serta dimuliakan dan menjadi suatu yang dicitakan tercapai bagi individu dalam hidupnya yang dinamis. Prof.Dr. Notonegoro dalam (Sanjaya dkk., 2015).

4. Keempat, adalah keterkaitan seluruh anggota masyarakat maupun organisasi sosial yaitu Jaringan Sosial. Jaringan ini dapat tercipta dari rasa simpati, kewajiban, norma pertuakaran dan civic engangement. Jaringan ini bisa terbentuk berdasarkan kesamaan agama, kepercayaan politik, kesamaan daerah, hubungan geneologis dll.

Sistem bagi hsail tanaman jeruk siam yang melibatkan dua pelah pihak yang bekerjasama dalam hal ini pemilik lahan dan penggarap, kerjasama ini melibatkan rasa saling percaya yang menjadi dasar kerjasama diantara keduanya. Kepercayaan diantara keduanya dapat memunculkan norma kejujuran, norma kejujuran yang sangat di junjung tinggi inilah yang membuat sistem bagi hasil tanaman jeruk siam tidak memerlukan perjanjian tertulis dan melibatkan pihak hukum. Sifat saling percaya ini juga menimbulkan rasa dan sifat rukun, saling menghormati diantara pihak-pihak yang terlibat.

Jaringan sosial juga tercipta dalam sistem bagi hasil tanaman jeruk siam, hal itu bisa digambarkan dalam kedekatan di antara anggota masyarakat seperti teman, saudara, dan tetangga. Hubungan ini bisa berupa kedekatan emosianal, yang menjadikan semakin eratnya hubungan di masyrakat dalam bekerja sama dalam rangka manikkan pendapatan perekonomian keularga. Jaringan sosial ini memunculkan empati seseorang, yang juga dapat membantu tetangga, keluarga, teman dll, yang kekurangan dan kesusahan dengan cara bekerjasama di sistem bagi hasil jeruk siam.

Setiap usaha tidak selalu mendapatkan jalan yang mulus, seperti halnya dengan usaha di tanaman jeruk siam ini, tidak jarang juga mendapat kerugian ataupun kegagalan. Resiko-resiko kerugian maupun kegagalan itu dapat timbul sewaktu-waktu, sebab kerugian pun dapat muncul melalui berbagai aspek. Umumnya yang menanngung kerugian adalah pemilik tanah, jika kerugian tersebut alami, muncul bukan karena kesalahan dan disengaja oleh penggarap, maka penggarap tidak dikenai ganti rugi apapun. Berbeda bila kerugian ini disebabkan oleh faktor penggarap, maka dialah yang akan membayar ganti rugi atau menanggung kerugian. Kerugian bisa terjadi jika penggarap teledor dengan pekerjaannya, seperti salah memberi obat yang harusnya digunakan untuk membasmi rumput malah di berikan ke tanaman, yang membuat buah dalam tanaman jeruk siam ini rontok. Faktor kerugian yang alami bisa karena sulit air dan juga kelebihan air yang membuat tanaman terendam. Namun, pada dasarnya setiap permasalahan yang ada akan selalu di musyawarahkan oleh kedua belah pihak.

\section{Solidaritas Sosial dalam Sistem Bagi Hasil}

Sebuah solidaritas merujuk pada suatu hubungan yang dilakukan oleh, anatara individu maupun kelompok yang didasarksn pada perasaan moral dan kepercayaan yang dianut bersama-sama dan juga diperkuat oleh pengalaman emosional (Durkheim, Teori Sosiologi Klasik dan Modern, 1986). Durkheim menkasifikasikan solidaritas menjadi dua tipe, takni organik dan mekanik. Menurut (Durkheim, 1986) ada ciri yang paling identik dalam solidaritas mekanik adalah 
sebuah ruang lingkup yang ketat dan hukum represive-nya. Kata hukum ini mendefinisikan sebagai semua perilaku yang tidak baik dapat mengancam dan melanggar kesadaran bersama yang kuat. Solidarita ini juga identik dengan tingginya homogenitas dalam kepercayaan.

Adapun solidaritas organik yang muncul dari rasa ketergantungan yang tinggi dalam masyarakat. Ketergantungan ini ikut naik seiring adanya spesialisasi-spesialiasi tertentu dalam pembagian pekerjaan. Durkheim dalam (Johnson, 1986) mengatakan bahwa solidaritas organik yang kuat dapat terjadi dengan adanya hukum restitutive dan bukan hukum represif yang ada di solidaritas mekanik.

Dalam sistem bagi hasil tanaman jeruk siam, kedua pihak yang terlibat akan menetapkan suatu kesepakatan dan persetujuan bersama hingga terjadi suatu perjanjian bagi hasil yang memiliki tujuan untuk memberi keuntungan diantara keduanya. Tidak hanya saling menguntungkan, perjanjian bagi hasil ini juga dapat menguatkan adanya sebuah solidaritas organik. Hal ini tejadi karena adanya rasa ketergantungan yang tinggi daintara pihak-pihak yang terlibat yaitu, pemilik lahan dan penggarap.

\section{Interaksi Sosial dalam Sistem Bagi Hasil}

Gillin (1954) mendefiniskan interaksi sosial sebagai sebuah hubungan baik yang dilakuan antar individu, antar kelompok maupun individu dan kelompok yang memiliki sifat dinamis. faktor imitasi, sugesti, simpati, dan juga identifikasi sering kali menjadi unsur pembentuk interaksi. Semua faktor itu bisa berjalan secara kolektif maupun juga secara terpisah (Soekanto, 1974). Interaksi sosial hanya akan bisa terjadi jika ada hubungan timbal balik baik kontak sosial maupun adanya komunikasi. (Soekanto, SOSIOLOGI Suatu Pengantar) membagi kontak sosial menjadi tiga bentuk yaitu;

- Pertama, interaksi antara individu dengan individu. Interaksi model ini dapat ditemui pada seorang anak kecil yang mempelajari berbagai kebiasaan yang ada pada keluarganya. Dalam interaksi terjadi suatu komunikasi yaitu proses dimana anggota masyaraktnya baru mempelajari norma dan nilai yang ada di sekitarnya.

- Kedua, interaksi individu dengan kelompok, interaksi tipe ini dapat ditemui pada individu yang merasa perilakunya tidak sesuai dengan norma dan nilai yang berlaku di mayarakat.

- Ketiga, interaksi kelompok dengan kelompok, interaksi ini dapat ditemui dalam kontestasi pemilu yang melibatkan interaksi antar partai politik dengan partai politik lainnya.

Dalam prosesnya, interaksi sosial tak hanya memunculkan suatu integrasi, namun juga memunculkan konflik, seperti halnya pada interaksi yang ada dalam sistem bagi hasil tanaman jeruk siam di desa Tegalsari ini, seiring dalam proses perwatan tanaman jeruk, suatu konflik juga akan muncul diantara pemilik lahan dan penggarap lahan. Konflik merupakan salah satu dari proses interaksi sosial, hal ini terjadi karena individu menyadari adanya perbedaanperbedaan yang muncul diantara mereka, hal itu dapat dipicu mulai dari perbedaan perilaku, emosi, serta kepentingan masing-masing individu.

\section{Kesimpulan}

Dalam hasil penelitian serta pembahasan yang telah dijelaskan sebelumnya, maka dapat di tarik kesimpulan yang menyatakan bahwa perjanjian sistem bagi hasil tanaman jeruk siam yang ada di Desa Tegalsari Kecamatan Tegalsari Kabupaten Banyuwangi merupakan salah satu perjanjian tradisional yang ada secara turun-temurun. Perjanjian ini terjadi karena persoalaan ketimpangan dalam kepemilikan tanah, yang merupakan persoalan lama dalam sektor pertanian 
karena pertumbuhan penduduk tidak di imbangi dengan pertambahan luas lahan. Sistem bagi hasil di dasari oleh rasa ketergantungan dan rasa saling percaya diantara kedua belah pihak. Sistem ini juga menguatkan adanya sebuah solidaritas organik di masyarakat. Di dalam interkasi pemilik lahan dan penggarap tak jarang menimbulkan konflik, namun hal itu berhasil diatasi dengan cara musyawarah tanpa melibatkan pihak hukum. Perjanjian bagi hasil tidak hanya dapat meningkatkan perekonomian, namun dapat menguatkan solidaritas dan integrasi di masyarakat.

Dari hasil kesimpulan yang disampaikan diatas, maka perlu peranan pihak lain dengan tujuan menjaga keutuhan dalam sistem bagi hasil. Diantaranya, yang pertama; baiknya dalam sistem bagi hasil melibatkan pihak ketiga dalam melakukan perjanjian, hal itu agar bisa ada penengah (tetua di desa) jika nantinya musywarah yang dilakukan antara pemilik lahan dan penggarap mengalami kebuntuan. Kedua; pemerintah baiknya memudahkan para petani dalam mendapatkan bahan penunjang pertanian seperti pupuk dan obat sawahm serta mengadakan pendampingan kepada pemilik tanah dan penggarap, agar kerjasama dalam sistem bagi hasil mendapat manfaat yang semakin maksimal. Ketiga, bagi seluruh peneliti terutama para sosiolog bisa untuk mengkaji lebih dalam megenai perjanjian sistem bagi hasil.

\section{Ucapan Terimakasih}

Alhamdulillah, dipanjatkan puji syukur kepada Tuhan Yang Maha Esa, atas kehendak serta ridho-Nya penelitian ini dapat diselesaikan. Peneliti sadari, tanpa ada dukungan, semangat dan doa dari berbagai pihak penelitian ini tidak dapat diselesaikan. Adapun pada kesempatan kali ini, peneliti sampaikan banyak-banyak terimakasih kepada:

1. Atas do'a kedua orang tua peneliti, diucapkan terimakasih karena doanya selalu menyertai perjalanan peneliti.

2. Seluruh dosen prodi Sosiologi Universitas Jember yang telah membimbing dan memotivasi peneliti hingga terselesaikannya artikel ini.

3. Seluruh informan atas data dan informasi yang telah diberikan kepada peniliti hingga peneliti mampu menyelesaikan artikel ini.

4. Seluruh sahabat yang telah sama-sama berjuang dan saling memotivasi dalam melakukan penelitian.

Semua pihak yang terlibat dalam peneletian ini, yang karena keterbatasan peneliti tidak dapat disebutkan satu persatu.

\section{Daftar Pustaka}

Coleman, J. (1990). Foundations of Social Theory. Cambridge Mass: Harvard University Press.

Collier, W. (1984). Dua Abad Penguasaan Tanah. Jakarta: Gramedia.

Durkheim, E. (1986). Dalam D. P. Johnson, Teori Sosiologi Klasik dan Modern (hal. 181). Jakarta: Gramedia.

Durkheim, E. (1986). Dalam D. P. Johnson, Sosiologi Klasik dan Modern (hal. 182). Jakarta: Gramedia.

Fukuyama, F. (2002). Kebijakan Sosial dan Pencapaian Kemakmuran. Jakarta: Qalam.

Gillin, G. (1954). Cultural Sociology, a revision of An Introduction to Sociology. In S. Soekanto, SOSIOLOGI SUATU PENGANTAR. PT RAJAGRAFINDO PERSADA.

Johnson, D. P. (1986). Teori Sosiologi Klasik dan Modern. Jakarta: Gramedia. 
Kroef. (1984). Dalam Collier, Dua Abad Penguasaan Tanah. Jakarta: Gramedia.

Moleong, L. J. (2010). Dalam Metode Penelitian Kualitatif. Bandung: PT. Remaja Rodakarya.

Pudjiawati, S. (2002). Sosiologi Pedesaan 1 dan 2. Jogyakarta: Universitas Gajah Mada Press.

Soekanto, S. (1974). Faktor-faktor Dasar Interaksi Sosial dan Kepatuhan pada Hukum. In HUKUM NASIONAL.

Soekanto, S. (t.thn.). SOSIOLOGI Suatu Pengantar. PT RAJAGRAFINDO PERSADA.

Wahyuningsih, T. (2011). SISTEM BAGI HASIL MARO SEBAGAI UPAYA MEWUJUDKAN SOLIDARITAS MASYARAKAT. 8. 